UDC 004.896

DOI: $10.25140 / 2411-5363-2018-4(14)-210-215$

Jan Semjon, Ján Grexa, Peter Mako

\title{
DESIGN OF DOCKING SYSTEM FOR MOBILE ROBOTICS PLATFORM TYPE AGV
}

\begin{abstract}
Urgency of the research. Automatic battery charging of AGV platforms allows you to maximize their potential. Safe and quickly positioning AGVs in a charging station equipped with appropriate contacts, reduces the charging time as well as the purchase price of the device.

Target setting. The aim of the solution is to design an automatic docking and charging station from a used hand-held charging station. In the design, it was necessary to ensure the appropriate position of the AGV platform against the docking station.

Actual scientific researches and issues analysis. The issue of fast and reliable charging of mobile service robots is highly up-to-date. The reason for this is the growing deployment of AGV platforms in various industrial or service sectors.

Uninvestigated parts of general matters defining. This article focuses on a specific solution for the provision of transport services. Transport services come from the need to transport medical supplies and medications in a multi-storey hospital building. The movement of the robot between the floors is solved by the use of lifts used by the personal of hospital.

The research objective. The aim of the research was to design a docking and charging station utilized an already purchased power-up charger. The design was aimed at creating an appropriate power transmission system between the charger and the AGV platform batteries. The price ceiling for the whole facility was worth $€ 2,000$.

The statement of basic materials. The use of docking and charging stations for mobile service robots is dependent on a number of parameters. In particular, the parameters depend on the area of use, the size of the battery to be charged, and the amount of robots being recharged at the station. Last but not least, charging time and purchase price are also important.

Conclusions. The task of the solution was to design a docking station design for the AGV platform. At the beginning, three variants were created, from which the most appropriate solution was chosen using the scoring method. However, before designing the docking station design, it was necessary to modify the existing AGV platform construction so that it could be connected to the docking station charging mechanism. The design of the docking station itself consisted of the design of the charging and charging mechanism. These mechanisms provide charge and guidance of the AGV platform to the docking station. Mechanisms are not dependent on each other, since the charging mechanism is activated later than the drive mechanism. Subsequently, a design of the docking station, which can be anchored to the floor or to the wall, was created. At the docking station there is a charger from Hoppecke, which provides the AGV platform charging. The design dimensions of the docking station have been greatly influenced by the size of the above-mentioned charger. It has been found that new and better technologies will not be needed at the docking stations in the future, as AGV platforms can be guided without their help. The development of new and better quality systems will bring new guidance options to AGV platforms and docking stations.
\end{abstract}

Key words: $A G V$; docking system; battery; mobile platform.

Fig.: 6. Table: 1. References: 6.

Problem definition. Industry 4.0 marks the current trend of digitization and automation of production. Basic visions emerged in 2011. With the onset of the Industrial Revolution, the development of AGV (Automated Guided Vehicle) platforms for automated material transport is also closely linked. Automated Vehicles in Industry 4.0 play an important role because they partially take on simple and repetitive activities that do not require human intervention. AGVs have different uses not only in industry but also in other areas. Over time, new intelligent factories will be created to use cybernetic-physical systems and take on the repetitive and simple activities that people have done so far $[1 ; 2]$. The first versions of AGV used navigational aids in the environment to navigate (for example magnetic passports, colour lines, floor wires). Thanks to advances in autonomous navigation, solutions are now available that allow for mapping and localization without the need for external navigation aids. The latest AGV models can map the environment using LIDARs (Light Detection and Ranging) and then create a virtual map of the environment. AGV is able to detect its exact location in this way and therefore works very accurately and precisely with regard to safety. AGV platforms include Mobile Industrial Robots (MiR), Omron Adept Technologies, SMP Robotics, VAHLE, WiBotic, Clearpath Robotics, Fetch Robotics, Swisslog, and the Slovak company CEIT. The issue of mobile AGV platforms is inseparably linked to the need to deliver energy to the system. In case of battery-powered AGVs, charging is required. Charging can be solved in a variety of ways. The simplest case is to manually connect the platform to the charging station, which however requires human intervention to (disrupt process automation. If we are trying to maximize the automation of material transport, it is necessary to solve the problem of automatic battery recharging [3].Several concepts are currently used to automatically charge mobile robots. The best-known ones are dock-

(C) Semjon J., Grexa J., Mako P., 2018 
TECHNICAL SCIENCES AND TECHNOLOGIES

ing stations, floor charging, and wireless charging. The article presents a proposal for automatic battery recharging for the AGV platform developed by a Slovak company. The manufacturer aims to bring to market a modern AGV platform based on the latest knowledge of autonomous navigation, localization and solving the problem of automatic energy recharging. The solution to this problem was to consider all currently available charging technologies on the market. On the basis of the acquired knowledge, three proposals for designing the integration of automatic charging technology into the system were developed. Based on cost analysis and complexity of the solutions developed, the final proposal was selected.

Use and parameters of AGV platform. The proposed AGV platform uses the latest knowledge of localization and autonomous navigation of mobile robots, can create a virtual map of its surroundings and then move it according to the chosen trajectory. With laser guidance and a virtual map, no lines, magnetic strips, or magnets placed in the floor need to be navigated. The first AGV platform is tested in the Kosice-Šaca hospital (Slovakia). It facilitates the work of the staff and is able to safely and fluently transport the necessary material to other floors through a lift that can be called. The proposed platform is shown in Fig. 1.

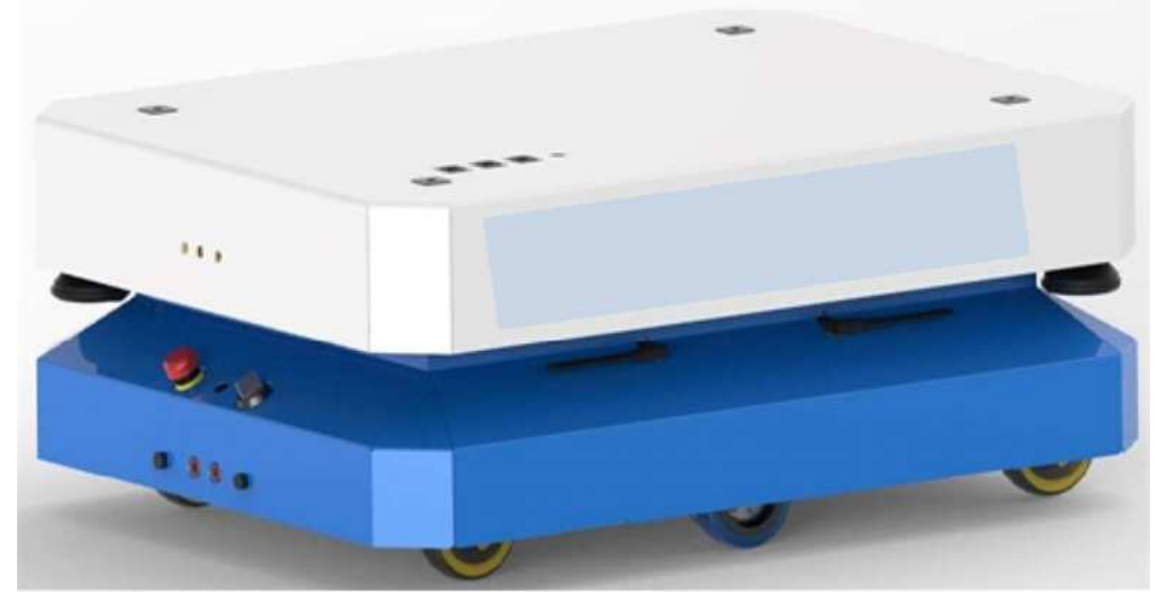

Fig. 1. AGV platform

Basic technical parameters of AGV platform:

- Maximum carrying capacity: $100 \mathrm{~kg}$.

- The maximum towable weight: $500 \mathrm{~kg}$.

- Maximum speed: $1.0 \mathrm{~m} / \mathrm{s}$.

- Battery life $10 \mathrm{~km}$ (with 50 Ah batteries).

- Charging device integrated in the home station.

- Machine weight $80.5 \mathrm{~kg}$.

AGV platform is ready to integrate various add-ons. The superstructure in the form of a robotic arm allows you to move or store the required goods in the designated area. The use of the arm is possible in several areas (e.g. the automotive industry). The electronically lockable box is the superstructure that is most commonly used in hospitals where it is used to transport medical supplies. Thanks to an electronic lock, this box cannot be opened while moving, making the material anti-theft. This add-on is not exclusively for the hospital environment, and its use is also possible in other sectors (e.g. hotels). AGV uses power via two $50 \mathrm{Ah}$ Hoppecke battery type $12 \mathrm{~TB} 50$ [4]. The batteries are connected in series to provide the $24 \mathrm{~V}$ required to power the system and the robot drives (AGV can run 10 kilometres per charge).

Proposal of docking station. The docking station consists of a frame on which the guiding mechanism and the cover plates are attached. The station has the possibility to attach it to the floor, but also to the wall, which will ensure against unwanted displacement. There is a charger inside the docking station to quickly charge the AGV platform. Powering the docking 
TECHNICAL SCIENCES AND TECHNOLOGIES

station is via a cable that is suitable for a conventional $230 \mathrm{~V}$ plug. In addition to the fact that the AGV platform can be effectively brought to the docking station by means of the sensors separately, in the case of a slight deviation in the docking station, a guidance mechanism is installed that can correctly rotate AGV platform for charging mechanism [5]. One of the advantages of the docking station is that it is possible to place it in any place in the hall without complicated intervention. The price of such charging devices is around $€ 2,200$ per piece. In Fig. 2, a docking station is shown along with an AGV platform that is suitably adapted for charging and flexible guidance into the docking station.

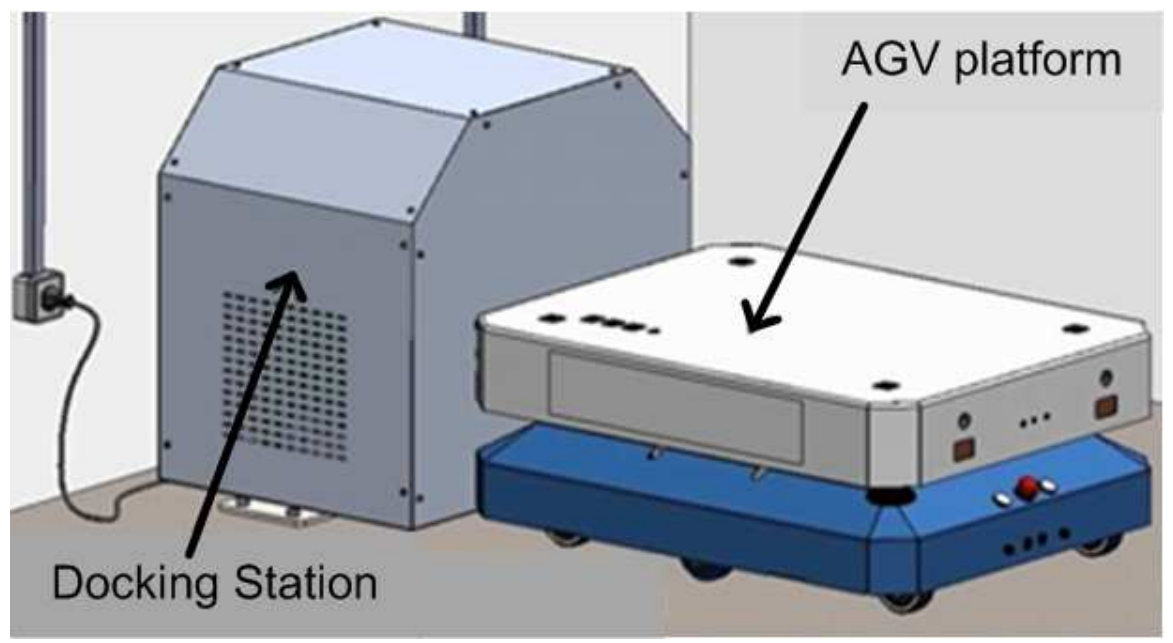

Fig. 2. $A G V$ and docking station

In Fig. 3 is a proposed AGV platform that is equipped with connectors. These connections consist of a guide cone hole and a charging contact.

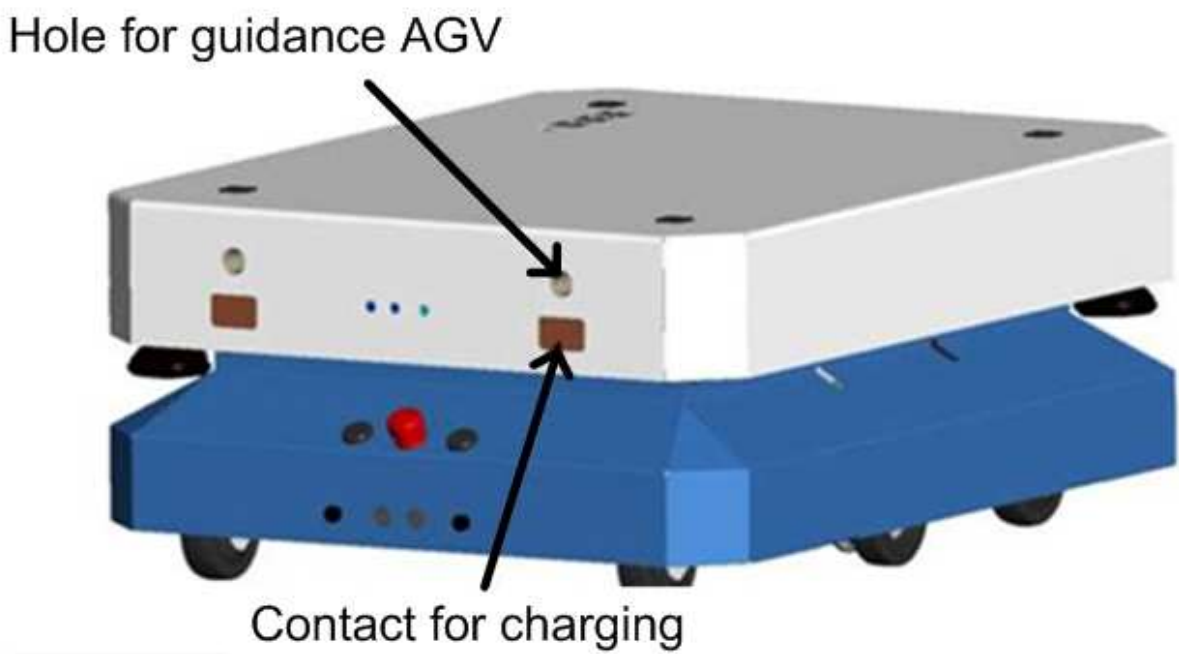

Fig. 3. Connections of the AGV platform to the docking station

Before designing the docking station itself, the design of the connection in the AGV platform is still needed. The connector structure is hidden under the top cover of the AGV platform. The top cover has out the required holes for charging and guiding. The simplicity of this design also reflects the resulting price. The production cost for the one connector of AGV platform is around $€ 70$ per piece. There are four such connectors on the AGV platform, so the final cost for modification the AGV platform is $€ 280$. Charging connection for AGV platform, fig. 4 consists of two main parts, which are the guiding and the charging contact (mechanism). 
TECHNICAL SCIENCES AND TECHNOLOGIES

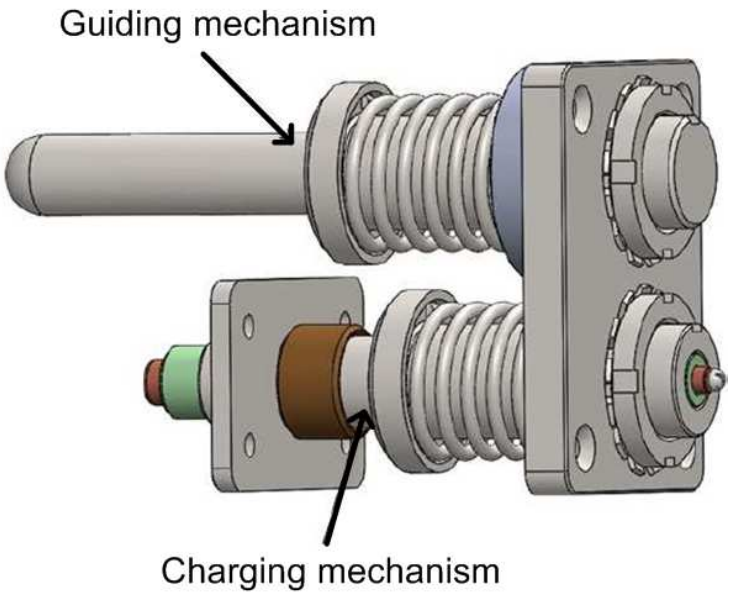

Fig. 4. Charging connection for AGV platform

The guide sleeve is fastened by screws to a frame to which a flange is attached due for extension of the screw thread. The charging contact is connected by means of screws that connect it to the insulating plate. The insulating plate is then used with other screws connected to the frame of the AGV platform. On the charging contact, a rubber insulation is provided to protect the frame of the AGV platform from electric current. There is a screw in the charging contact which connects the conductive contact with the charging contact. The entire connection solution is hidden under the top cover of the AGV platform. In this cover, holes are cut out so that the AGV platform can be routed through the guiding mechanism and charged with the charging mechanism. The first step in designing the docking station is to create a rigid frame that can withstand unexpected impacts, as there may be different situations in the production halls. Figure 5 shows a frame on which there is also a charging and guidance mechanism. This frame is formed from a hollow square profile.

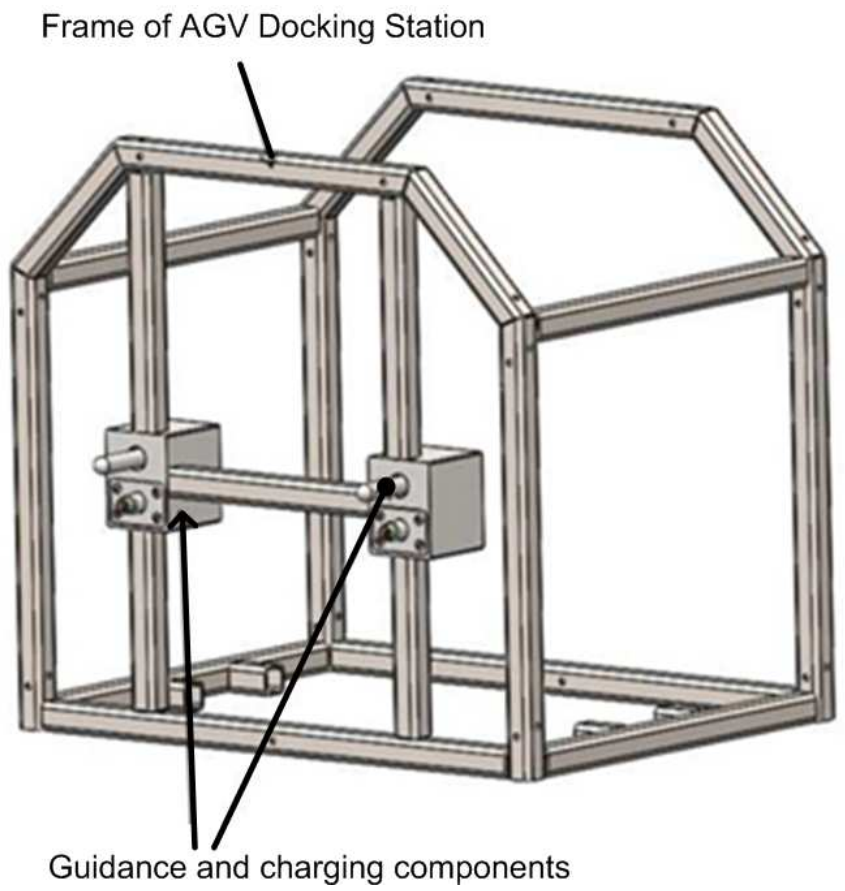

Fig. 5. Connections of the AGV platform to the docking station

In Fig. 6 shows a charger from Hoppecke, which is already incorporated in the docking station [6]. The dimensions of this design are largely influenced by the size of the charger to be mounted in the docking station. This problem with the construction was easily solved by enlarging the docking station. 


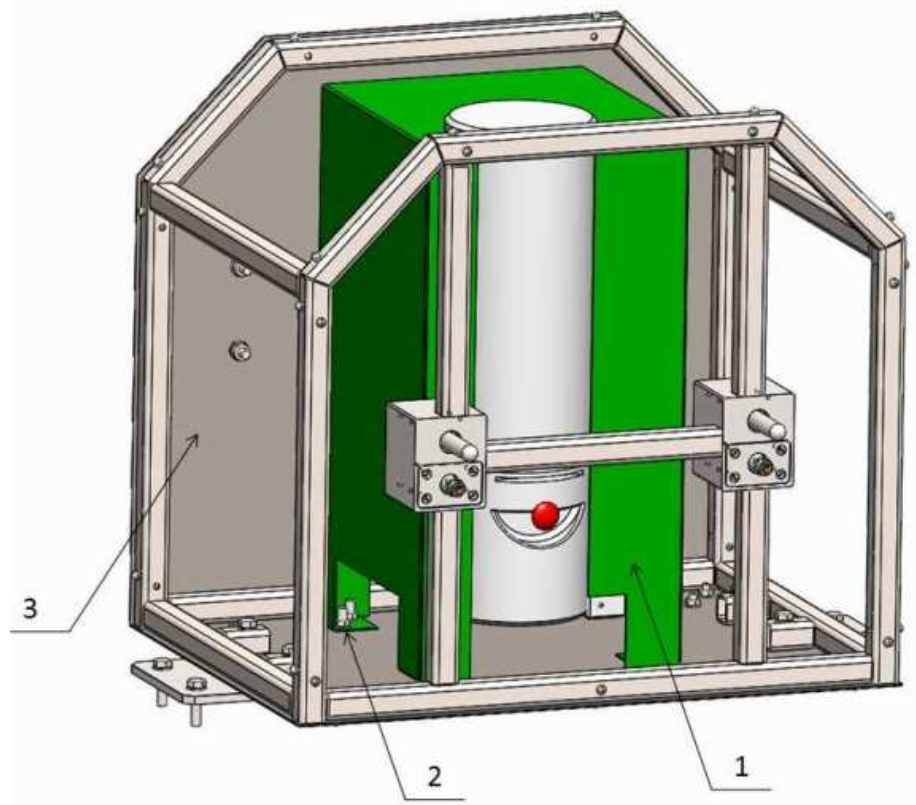

Fig. 6. Docking station without cover:

1 -Hoppecke charging device; 2-Attaching the charger to the docking station;

3- The rear part of the docking station for attachment to the wall

The docking station is not very compact, but robust and shock-resistant. If necessary, the docking station can also be moved to other locations. The charging mechanism is designed to withstand even tougher impacts and careless handling. The basic information on the docking station is shown in Table.

Table

Parameters of the charging and docking station

\begin{tabular}{|l|c|}
\hline Base dimensions of docking station (Width x Depth $\times$ Height) $[\mathrm{mm}]$ & $676 \times 505 \times 632$ \\
\hline Basic dimensions of the guide mechanism (Width $\times$ Depth $\times$ Height) $[\mathrm{mm}]$ & $80 \times 165 \times 100$ \\
\hline Weight of the charging and docking station [kg] & 52 \\
\hline
\end{tabular}

The cost of manufacturing, welding and assembly work is estimated at $€ 500$. The total purchase price for the materials is $€ 1475$, which means that the total cost of one docking station is $€ 1975$.

Conclusions. The task of the solution was to design a docking station design for the AGV platform. At the beginning, three variants were created, from which the most appropriate solution was chosen using the scoring method. However, before designing the docking station design, it was necessary to modify the existing AGV platform construction so that it could be connected to the docking station charging mechanism. The design of the docking station itself consisted of the design of the charging and charging mechanism. These mechanisms provide charge and guidance of the AGV platform to the docking station. Mechanisms are not dependent on each other, since the charging mechanism is activated later than the drive mechanism. Subsequently, a design of the docking station, which can be anchored to the floor or to the wall, was created. At the docking station there is a charger from Hoppecke, which provides the AGV platform charging. The design dimensions of the docking station have been greatly influenced by the size of the above-mentioned charger. It has been found that new and better technologies will not be needed at the docking stations in the future, as AGV platforms can be guided without their help. The development of new and better quality systems will bring new guidance options to AGV platforms and docking stations.

\section{Acknowledgements}

This publication is the result of the project implementation: VEGA 1/0872/16 - Výskum syntetických a biologicky inšpirovaných lokomócií mechatronických sústav v členitom teréne 


\section{References}

1. Korbel, $P$. Průmyslová revoluce 4.0: Za 10 let se továrny budou ř́dit samy a produktivita vzroste o třetinu. Hospodářské noviny [online]. 2015-05-17 [cit. 2015-09-20].

2. Marcinko, P. at al. (2016). Proposal of Tracked Robot with Folding Arms. In: American Journal of Mechanical Engineering. Vol. 4, no. 7, pp. 372-375. ISSN 2328-4102.

3. Janoš, R. at al. (2013). Design of Hybrid Mobile Service Robot. In: Applied Mechanics and Materials: ICMERA 2012 : International Conference on Biomechanics, Neurorehabilitation, Mechanical Engineering, Manufacturing Systems, Robotics and Aerospace : Bucharest, Romania : 26-28 October 2012. Vol. 245 (2013), p. 255-260. - ISBN 978-303785554-6.

4. Hoppecke. Retrieved from https://www.hoppecke.com/en/product/trak-bloc.

5. Acosta Calderon, C.A. at al. (2014). Docking System and Power Management for Autonomous Mobile Robots Applied Mechanics and Materials Vol. 590, pp. 407-412.

6. Hoppecke. Retrieved from https://www.hoppecke.com/en/product/trak-basic.

УДК 004.896

\section{Ян Семйон, Ян Грекса, Петер Мако \\ ПРОЕКТУВАННЯ ДОК-СТАНЦЇ̈ ДЛЯ МОБІЛЬНОЇ РОБОТОТИЗОВАНОЇ ПЛАТФОРМИ ТИПУ АGV}

Актуальність теми дослідження. Автоматична зарядка акумуляторів на платформах типу AGV дає змогу максимально використовувати їхній потенціал. Безпечне та швидке розміщення $A G V$ на док-станції, щяо оснащена відповідними контактами, скорочує час зарядження, а також вартість покупки пристрою.

Постановка проблеми. Метою роботи є розробка автоматичної док-станиії $і$ зарядного пристрою із вжсивної портативної зарядної станиії. При проектуванні необхідно було забезпечити належне положення платформи AGV щодо док-станції.

Аналіз останніх досліджень і публікацій. Проблема швидкої й надійної зарядки мобільних сервісних роботів дуже актуальна. Причиною цього є зростаюче розгортання платформ автономних керованих транспортних засобів (AGV) у різних промислових і сервісних застосуваннях.

Виділення недосліджених частин загальної проблеми. Дана стаття присвячена конкретному ріменню для надання транспортних послуг. Транспортні послуги виникають через необхідність перевозити медикаменти і медикаменти в багатоповерхові будівлі лікарні. Рух робота між поверхами реалізується за допомогою ліфтів, які використовуються персоналом лікарні.

Постановка завдання. Мета дослідження полягала в тому, щоб спроектувати док-станиію з використанням вживаного зарядного пристрою. Розробка була спрямована на створення відповідної системи передачі енергії між зарядним пристроєм і батареями платформи AGV. Обмеження по вартості всього обєкту становило2000 євро.

Виклад основного матеріалу. Використання стикувальних $і$ зарядних станиій для мобільних сервісних роботів залежить від багатьох параметрів. Зокрема, параметри залеэсать від галузі використання, розміру батарей для зарядки і кількості роботів, щзо заряджаються на станції. Нарешті, щуо не мени важливо, час зарядки й ціна покупки також важливі.

Висновки відповідно до статmі. Завданням було розроблення конструкиії док-станиії для платформи $A G V$. Ha початку було створено три варіанти, з яких було вибрано найбільш відповідне рімення з використанням методу оцінки. Однак перед проектуванням конструкиї док-станиії було необхідно змінити наявну конструкцію платформи $A G V$, щоб вона могла бути підключена до механізму зарядки док-станиії. Конструкція док-станиї передбачає наявність зарядного механізму. Ці механізми забезпечують зарядку і управління платформою AGV до док-станиії. Механізми не залежать один від одного, так як механізм зарядки активується пізніше, ніж механізм приводу. Згодом була розроблена конструкиія док-станиії, яку можсна закріпити на підлозі або на стіні. На док-станиї̈ є зарядний пристрій від Норреске, який забезпечує зарядку платформи AGV. На габаритні розміри док-станції істотно впливали розміри вищезгаданого зарядного пристрою. Було встановлено, щзо в майбутньому на док-станції не будуть потрібні нові й більш досконалі технологї̈, оскільки платформи AGV можна орієнтувати без їх допомоги. Розробка нових $і$ більш якісних систем принесе нові можсливості управління для платформ AGV i док-станиій.

Ключові слова: $A G V$; стикувальна система; акумулятор; мобільна платформа.

Рис.: 6. Табл.: 1. Бібл.: 6.

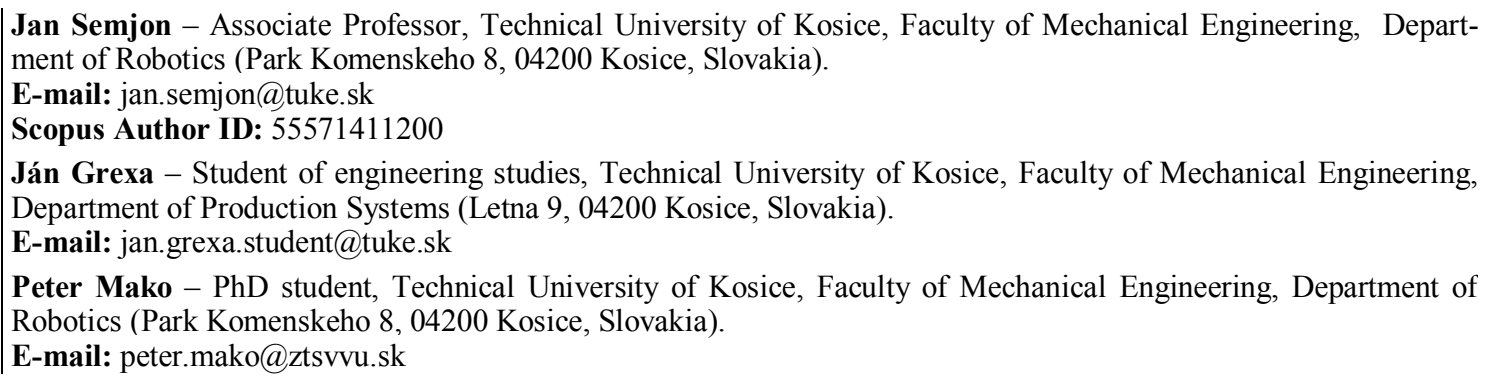

Semjon, J., Grexa, J., Mako, P. (2018). Design of docking system for mobile robotics platform type AGV. Technical sciences and technologies, 4 (14), 210-215. 